\title{
PREDICTIVE POTENTIAL AND RISKS OF SELECTED BANKRUPTCY PREDICTION MODELS IN THE SLOVAK BUSINESS ENVIRONMENT
}

\author{
Beata GAVUROVA', Miroslava PACKOVA ${ }^{\mathbf{2}}$, \\ Maria MISANKOVA ${ }^{3}$, Lubos SMRCKA ${ }^{4}$ \\ 1,2 Department of Banking and Investment, Faculty of Economics, \\ Technical University of Kosice, Nemcovej 32, 04001 Kosice, Slovakia \\ ${ }^{3}$ Department of Economics, Faculty of Operation and Economics of Transport and \\ Communications, University of Zilina, Univerzitna 1, 01026 Zilina, Slovakia \\ ${ }^{4}$ Department of Strategy, Faculty of Business Administration, University of Economics Prague, \\ nam. W. Churchilla 4, Prague, 130 67, Czech Republic \\ E-mails: ${ }^{1}$ beata.gavurova@tuke.sk(correspondingauthor); ${ }^{2}$ miroslava.packova@tuke.sk; \\ ${ }^{3}$ maria.misankova@fpedas.uniza.sk; ${ }^{4}$ smrckal@vse.cz
}

Received 27 June 2017; accepted 31 October 2017

\begin{abstract}
In our study, we focused on the assessment of four bankruptcy prediction models, to figure out which model is most appropriate in the conditions of the Slovak business environment. Based on the previous research within the Slovak conditions, we set a portfolio of 4 models to be assessed: Altman model (1984), Ohlson model (1980), indexes IN01 and IN05 that were validated on the sample of 700 Slovak companies. Based on previous studies we expected that IN indexes are superior to Ohlson and Altman model. The excellency of our research lies in validation and assessing the accuracy of bankruptcy prediction models at three levels: the overall accuracy, accuracy of the bankruptcy prediction, and the non-bankruptcy prediction accuracy. This analytical structure enables to look at the topic more complexly and to increase the objectification of accuracy of analysed models. Based on the results, we showed that Ohlson model is not applicable to predict bankruptcy in the Slovak conditions as reached the lowest bankruptcy prediction ability even if has high non bankruptcy prediction ability. On the other hand, we have confirmed our expectation about the bankruptcy prediction ability of index IN05, that is proven to be superior to Ohlson and Altman model and so is the most appropriate model for Slovak business environment.
\end{abstract}

Keywords: bankruptcy, prediction models, bankruptcy and non-bankruptcy prediction accuracy, validation of prediction models, Altman model, Ohlson model, IN indices.

JEL Classification: G33, C10, C30.

\section{Introduction}

The first studies on the prediction of bankruptcy, that were used as an early warning signal in case of the situation worsening with the risk of this resulting in bankruptcy, were published in the early 20th century (the definitions of bankruptcy see in Boratyn- 
ska 2016). In the early days, only one indicator was used to predict the future financial situation of enterprises (Beaver 1966) that could reflect the financial position of the company the best. Later, in parallel with the development of mathematical and statistical methods, predictive bankruptcy models were created. They were developed by the combination of financial ratios and other variables taking the whole financial situation in one number into account, under which the company is classified as an enterprise with or without the risk of bankruptcy in a certain time frame (an overview of models in Bellovary et al. 2007).

Since the first model published in 1968 (Altman model), many models have been developed. Usually, traditional statistical methods were used, however in the recent past artificial networks started to be very popular (Bellovary et al. 2007). In spite of available data needed for development of bankruptcy prediction models, in Slovakia and Czech Republic the development of bankruptcy prediction models is not very often in the research studies, when comparing with the other states (some research was conducted for example by Mihalovič 2016; Paseková et al. 2016). Hence, for the purposes of this paper, we selected four models created in other than Slovak conditions to validate them on the sample of Slovak companies. Even if these models we not created for Slovak companies, they have been identified as the most appropriate ones (Delina, Packová 2013).

The excellency of our research lies in validation and assessing the accuracy of bankruptcy prediction models at three levels: the overall accuracy, accuracy of the bankruptcy prediction, and the non-bankruptcy prediction accuracy. This analytical structure enables to look at the topic more complexly and to increase the objectification of accuracy of analyzed models. When we look at the available studies in the field, many authors deal only with the overall accuracy of bankruptcy prediction models in their studies which in the most cases lead to bias results. As a problematic issue we also see that the investigated models are often not sensitive enough to worsen the financial situation of an enterprise. Just by the combination of these three points of view, a comprehensive look at the accuracy of the models and the choice of optimal models reflecting the real situation of companies is achieved. These three levels of accuracy assessment are complementary, whereby in the accuracy of bankruptcy and non-bankruptcy an inversion relationship can be found. Based on that, these three accuracies should be investigated together.

The content and process structure of the paper was defined in order to meet the research objectives. The introductory part consists of a research that opened the issue of validation of bankruptcy prediction models and emphasized the need for its solution. In the next part we deal with the methodological aspects of our research and analytical processes, which open up the scope for the evaluation of the results and their discussion. In the discussion, we also call for the practical and scientific applicability of the results and the need for continuous research in this area. Finally, we evaluate the achievement of the goal of the paper and its research potential. 


\section{Theoretical background}

Application of the bankruptcy models is a systematic process of predicting a business failure based on the financial data that enables them to be classified into a prosperous, declining or failure area. Their results are used by entities trying to prevent bankruptcy, and thus eliminating the processes that lead to a failure, or entities that will not to be affected by the bankruptcy of other companies. In the theory and practice a wide range of bankruptcy models is applied, whereby in the research we can found more than 150 different models (Bellovary et al. 2007). Their application is structured by several differentiation aspects: e.g. models for the financial sector, manufacturing companies, companies in the service sector (including Internet), etc. When making a choice on selection, user preferences related to the usability of the results are important. The sectoral structure and its specificities stimulated also the development of sectoral models. Among the most recent, we can mention models for the banking sector (e.g. Pam 2013; Erdogan 2008; Lanine, Vennet 2005) or for agriculture (Rajin et al. 2016; Bieliková et al. 2014; Vavřina et al. 2013) and increasingly developed models for Internet companies. The bankruptcy models are specifically designed also for different segment of companies (according to their type or size), with significant differences especially in different states or continents (Taffler 1984; Ékes, Koloszár 2014; Blach, WieczorekKosmala 2012). The relevance of bankruptcy models is determined by constant changes in the external environment of companies, globalization processes, the extinction of old industries and the emergence of new ones, etc. Thereby, the models need to be validated in the different conditions, different time horizons, etc.

\section{Validation of prediction models}

The role of bankruptcy prediction models is to predict a future financial position with the highest accuracy, within which the companies are classified among the successful businesses and companies at risk of bankruptcy. In the classification process (or in the validation process) four situations can happen, as stated in the Table 1.

Table 1. Classification of results of the model prediction

\begin{tabular}{lll}
\hline & Prediction - bankruptcy & Prediction - non-bankruptcy \\
\hline Fact - bankruptcy & The correct result (TP) & Error type I (FN) \\
\hline Fact - non-bankruptcy & Error type II (FP) & The correct result (TN) \\
\hline
\end{tabular}

Source: own processing.

As follows from the relations above, the overall predictive ability of the model reflects how many of the total number of enterprises could the model correctly classify as bankrupt or businesses that do not get into bankrupt. This relationship can be expressed using the following equation:

$$
P=(T P+T N) /(T P+T N+F P+F N) .
$$

It is still true, that the higher the predictive ability of the model, the more likely that the model correctly classifies the analyzed company. On the other hand, the model does not 
always correctly classify companies, creating a problem of occurrence of errors type I and II. These error models are being expressed through the following links:

$$
\begin{aligned}
& \text { Error Type } 1=F N /(F N+T N), \\
& \text { Error Type } 2=F P /(F P+T P) .
\end{aligned}
$$

By analogy, the higher the error type I and II, the lower the predictive ability of the model, which entails certain costs.

The costs of both types of errors were identified in the publication of Altman (1982). The costs of error type I include:

- Management does not carry out remedial action because they are not aware of the seriousness of the situation.

- Investors may lose their investment because they do not have enough information about a business issue.

- Auditors and the company may be exposed to penalties and lose their "goodwill".

The costs of error type II include:

- In classifying a going concern as a company with financial problems, a self-fulfilling prophecy can occur.

- Auditors can spend more costs for peer review of financial problems to avoid bankruptcy.

When comparing the costs associated with the error type I and II it is clear that the error type I is associated with higher costs compared to the error type II (Bellovary et al. 2007; Kuo 2013; Gepp, Kumar 2008; etc.).

Many authors determined their research to the validation of already created models in order to evaluate their predictive ability on companies of specific country or sector. Most of studies are focused on the most known models such as Altman model and Ohlson model and their revised models. Lennox (1999) concluded that the Ohlson model achieves greater predictive power than Altman model. These conclusions were confirmed by Kordlar and Nikbakth (2011), Araghi and Makvandi (2013). Altman $\mathrm{Z}$-score and logit model - Ohlson O-score were also compared in the study of $\mathrm{Ku}$ mar, R. G. and Kumar, K. (2012). They concluded, that Ohlson model has greater predictive power than Altman model. Higher accuracy of Ohlson logit model was also proven in the study of Ingram and Frazier (1982) and Charitou et al. (2004). Comparison of other studies were carried out also by Tam (1991), Bukovinsky (1993) and others. In terms of Slovak companies, model validation was made by Delina and Packová (2013) who compared the performance of Altman model and index IN05 that proved to be the superior within the Czech Republic environment. They concluded that the index IN05 compared with Altman model achieved higher accuracies of prediction. A similar finding was found out by Lesáková and Gundová (2015). The predictive ability of Altman model was analyzed also by Gulka (2016), who pointed to the lack of precision in the Slovak conditions. Gundová (2014) compared in her study the performance of Ohlson model, Altman model and IN05 - the highest accuracies were achieved by Ohlson model and the worst accuracies by index IN05. 
It follows that the results of comparison of the models vary, not only in view of the economy, in which they are applied, but also within one economy around the same time. Looking at the analysis of Slovakia it is necessary to note that in most cases they bonded to the very small sample, sometimes to a few tens of observations with the result of vastly different results. Because of this reason we chose a relatively larger sample in our article, factually 700 , their annual accounts within four years were analyzed, which represents 2800 observations. By using the larger sample, we expect to get more relevant results in comparison with other studies carried out within the Slovak business environment.

As mentioned above, most of studies validate models such as Altman and Ohlson model on different samples and within the Slovak and Czech conditions IN indexes (IN01, IN05) are very popular as they proved high predictive ability. Hence, for validation and comparison purposes 4 models were selected:

- Altman model (1984) as one of the most widely used models in the literature as in normal use. The model is based on the multidimensional discriminant analysis (MDA) method, which is within the given methodology the most successful model as it relates to performance.

- Ohlson model (1980) as the best known and most powerful model constructed using logistic regression.

- Indices IN01 and IN05 are selected as models that achieve the best results in conditions of the Czech Republic.

The first and currently the best-known model developed using the multivariate discriminant analysis is Altman's (1968) 5-factor model, designed for manufacturing companies, negotiable on the capital market, which reached the percentage of bankruptcy prediction of $95 \%$ one year ahead, $72 \%$ two years ahead, and for three years $48 \%$ in advance. The underlying source of information the Altman model is based on, has the empirical data on 33 not so successful companies in the last five years before their bankruptcy and data on 33 going concerns over the same period. The sample of bankrupting enterprises consisted of those producers who bankrupted from 1946 to 1965 . Of the 22 potentially useful ratios that Altman divided into five basic categories (liquidity, profitability, indebtedness, solvency and activity), 5 most significant indicators with respective weights corresponding to their importance were selected by MDA:

$$
\begin{aligned}
& \text { Altman Z-score }=0.012 * \text { Net working capital / Total assets }+ \\
& 0.014 * \text { Retained earnings / Total assets }+0.033 * \text { EBIT / Total assets }+ \\
& 0.006 * \text { Market value of equity / Outside capital }+ \\
& 0.999 * \text { Turnover (sales) / Total equity. }
\end{aligned}
$$

As a dividing value $Z=2.675$ was set, while enterprises with a value of $Z$-score which is less than a dividing line were threatened by bankruptcy.

In 1983, Altman revised its model because its original model could be applied only to companies traded on the capital market. Compared to the original model, besides weighing indicators also one indicator was changed and the dividing boundary was shifted from the value of 1.81 to 1.23 (Altman 1984): 
Altman $Z^{\prime}$ score $=0.717 *$ Net working capital / Total assets +

$0.847 *$ Retained earnings / Total assets $+3.107 *$ EBIT / Total assets +

$0.420 *$ The capital / Outside capital $+0.998 *$ Turnover (sales) / Total equity.

Many subsequent studies have been focused precisely on the validation of the original and revised Altman model (Soon et al. 2013; Sulub 2014; Meeampol et al. 2014; Lifschutz, Jacobi 2010 and others) as well as on re-recording of weights of its ratios to increase predictive power (Grice, Ingram 2001; Anoop et al. 2007; Karas et al. 2013 and others).

The most famous author of the bankruptcy logit models is Ohlson (1980), who was also the first one to apply logit analysis in predicting bankruptcy. His model was created on a sample of 105 going bankrupt and 2058 prosperous businesses that were in the years 1970-1976 traded for at least three years on the US stock exchange. His analysis was based on nine indicators, the choice of which was not theoretically based. The equation of Ohlson's O-score has the following form:

$O-$ score $=-1.32-0.40 * \ln ($ Total assets / GDP price level $)+$

6.03* Total liabilities / Total assets $-1.43 *$ Working capital / Total assets +

0.076* Current liabilities / Current assets $-2.37^{*}$ EAT / Total assets -

$1.83 *$ Expenses for financial operations / Total liabilities +

$0.285^{*}$ ( 1 if the net profit in the last two years was negative, otherwise 0) -

$1.72 *$ ( 1 if the total liabilities exceeded total assets, otherwise 0) -

$0.521 *(E A T t-E A T t-1) /(|E A T t|+|E A T t-1|)$.

As the classifying limit 0.38 was set - if the company reaches O-score greater than 0.38 it falls into bankruptcy. At the given limit, the Ohlson's logit model correctly classified the companies with $96 \%$ accuracy 1 and 2 years ahead.

Under the conditions of the Czech Republic some models were created by Neumaier spouses. They created some predictive indices. In 1995 the IN95 was constructed. Four years later, the authors of the index IN95 wanted to bind to value creation and thus they created the index IN99. Both views, bankruptcy one and creditworthy one merged in 2002 into one index IN01 (each index was created using the data at the time of its creation). Index IN01 has the following form:

$$
\begin{aligned}
& \text { IN } 01=0.13 * \text { Total equity / Outside capital }+0.04 * \text { EBIT / Cost interest }+ \\
& 3.92 * \text { EBIT / Total capital }+0.21 * \text { Total revenues } / \text { Total assets }+ \\
& 0.09 * \text { Current assets / (Current liabilities }+ \text { Current bank loans }) .
\end{aligned}
$$

In a study from 2005 the authors tested the predictive value of the indices for industrial enterprises for the year 2004. The sample consisted of 1526 enterprises broken down by threats of bankruptcy (the methodology used by banks) and by value creation. As a result, Index IN95 has improved its percentage from 75\% (in the compilation of the index) to $80 \%$, Index IN99 decreased with its success below $50 \%$ and the Index IN01 slightly reduced its percentage from $76 \%$ to $74 \%$. Given the above results, Index IN05 was constructed, which differs it from IN01only in the weight of the indicator EBIT / 
Total capital - 3.92 to 9.97. Compared to the index IN01, the lower classification limit of bankruptcy was changed, which moved from 0.75 to 0.9 (Neumaierová, Neumaier 2005; Váchal et al. 2013).

\section{Methodology and data}

Validation of Altman and Ohlson models and IN indices is carried out on a sample of Slovak companies to verify their accuracy in predicting bankruptcy, resp. non-bankruptcy 1 or 2 years ahead. Based on the validation we will be able to assess which models are applicable in the Slovak environment. Validation sample consists of 700 companies that publish their financial statements in the period 2009-2014. The data were gained from the database CRIBIS (CRIF - Slovak Credit Bureau, s.r.o.). The largest part of the sample consists of companies which main activity falls within the sector of wholesale and retail trade and repair of motor vehicles and motorcycles, in which most businesses went bankrupt. The least amount of companies in our sample do their business in the field of hospitality services.

From the whole sample, $20 \%$ of companies (140) got into bankruptcy. The analyzed companies that came into bankruptcy declared bankruptcy for three years: 2012, 2013 and 2014. The largest part of companies came into bankruptcy in 2014 (94), while in 2013 it was only 37 companies.

In fact, abstracted from our samples in 2014, 407 companies bankrupted, while in 2013 it was 13 companies less (394) (according to CRIF).

Due to the studies carried out as in Slovakia and other countries, we formulated the following hypotheses concerning the performance of validated models:

- Working Hypothesis 1: Index IN 05 achieves higher prediction accuracy than index IN 01;

- Working Hypothesis 2: Indices IN01 and IN05 achieve higher prediction accuracy than Altman model;

- Working Hypothesis 3: Ohlson model achieves higher prediction accuracy than the MDA models (Altman model and IN indices).

\section{Results}

The results of analyses are structured into three complementary parts, analogous with dimension of accuracy of bankruptcy prediction models.

\subsection{Total accuracy}

The overall accuracy of the model is determined by the success to predict bankruptcy and non-bankruptcy of a company. The values of the overall accuracy of validated models are shown in the following Table 2.

As it can be seen in Table 2 above the highest overall accuracy is reached by Ohlson model $-85 \%$, e.g. from 700 companies it properly identified about 595 of them, in the prediction of one and two years ahead. When comparing IN indices and Altman model, 
Table 2. Overall accuracy of validated models

\begin{tabular}{ccc}
\hline Overall accuracy & One year ahead (\%) & Two years ahead (\%) \\
\hline ALTMAN & 69.71 & 68.86 \\
\hline IN01 & 72.14 & 70.00 \\
\hline IN05 & 67.71 & 66.57 \\
\hline Ohlson & 85.43 & 84.43 \\
\hline
\end{tabular}

Source: own processing.

Index IN05 reached about $2 \%$ lower overall predictive power of the model than Altman model, while the index IN01 reached within MDA models the best results. Most authors focused in their study on the overall predictive power, and on this basis, the authors compared their model with other models that could predict bankruptcy. This approach is not considered the most suitable, because at first glance good results in the overall predictive power may not mean that the model is good. Justification will be provided in the next section, in which we evaluate the accuracy of prediction of bankruptcy and non-bankruptcy models.

\subsection{Bankruptcy accuracy}

As we can see in Table 3, most bankruptcies were classified correctly one year ahead by Index IN05 with nearly 83\% success, while the index IN01 identified only three fewer bankruptcies. The worst record in predicting bankruptcy can be seen at Ohlson model that identified properly only $35 \%$ of business failures. The same sequence in the evaluation of the predictive power of the models in predicting bankruptcies is also to predict two years in advance.

Table 3. Model I validation - one year ahead forecast

\begin{tabular}{ccccccccc}
\hline \multirow{2}{*}{1 year ahead } & \multicolumn{2}{c}{$\begin{array}{c}\text { Non-bankruptcy } \\
\text { prediction accuracy }\end{array}$} & \multicolumn{2}{c}{ Error Type II } & \multicolumn{2}{c}{$\begin{array}{c}\text { Bankruptcy prediction } \\
\text { accuracy }\end{array}$} & \multicolumn{2}{c}{ Error Type I } \\
\cline { 2 - 10 } & Count & $\%$ & Count & $\%$ & Count & $\%$ & Count & $\%$ \\
\hline ALTMAN & 380 & 67.86 & 180 & 32.14 & 108 & 77.14 & 32 & 22.86 \\
\hline IN01 & 392 & 70.00 & 168 & 30.00 & 113 & 80.71 & 27 & 19.29 \\
\hline IN05 & 358 & 63.93 & 202 & 36.07 & 116 & 82.86 & 24 & 17.14 \\
\hline Ohlson & 549 & 98.04 & 11 & 1.96 & 49 & 35.00 & 91 & 65.00 \\
\hline
\end{tabular}

Source: own processing.

As Table 3 and Table 4 shown, within the analysis of the results of bankruptcy prediction models in time we can observe a decrease in the accuracy of the model. This phenomenon occurs in predicting the current financial situation of enterprises which businesses have significantly worsen financial indicators in the period immediately preceding the bankruptcy. 
B. Gavurova et al. Predictive potential and risks of selected bankruptcy prediction models in the Slovak ...

Table 4. Model I validation - two years ahead forecast

\begin{tabular}{lcccccccc}
\hline \multirow{2}{*}{$\begin{array}{c}2 \text { years } \\
\text { ahead }\end{array}$} & $\begin{array}{c}\text { Non-bankruptcy } \\
\text { prediction accuracy }\end{array}$ & \multicolumn{2}{c}{ Error Type II } & \multicolumn{2}{c}{$\begin{array}{c}\text { Bankruptcy } \\
\text { prediction accuracy }\end{array}$} & \multicolumn{2}{c}{ Error Type I } \\
\cline { 2 - 10 } & Count & $\%$ & Count & $\%$ & Count & $\%$ & Count & $\%$ \\
\hline ALTMAN & 389 & 69.46 & 171 & 30.54 & 93 & 66.43 & 47 & 33.57 \\
\hline IN01 & 396 & 70.71 & 164 & 29.29 & 94 & 67.14 & 36 & 25.71 \\
\hline IN05 & 365 & 65.18 & 195 & 34.82 & 101 & 72.14 & 39 & 27.86 \\
\hline Ohlson & 549 & 98.04 & 11 & 1.96 & 42 & 30.00 & 98 & 70.00 \\
\hline
\end{tabular}

Source: own processing.

As mentioned above, the highest overall accuracy was reached by Ohlson model. Looking at the results of the model in predicting non-bankruptcy of the companies, accuracy is more than $98 \%$ one and two years ahead. Error type II, e.g. misclassification of nonbankrupting company as an enterprise that gets in bankruptcy is very low (less than $2 \%)$. Such accuracy is above the average, but on the other hand, accuracy of Ohlson's model in predicting bankruptcy is only $35 \%$ and the error type I, e.g. incorrect classification of business failures as business which is flourishing reaches more than $65 \%$. This situation is caused by the fact that Ohlson model it is not sufficiently "sensitive" to the differences between bankrupted and non-bankrupted companies. For this reason, the model classifies most businesses as a going concern and because of the fact, that most businesses $(80 \%)$ are prosperous, the model achieves a quite high overall accuracy. On that basis, we will not consider this model as the appropriate one, despite the fact, that the overall prediction of the model is quite high.

A similar case where a higher bankruptcy prediction is accompanied by lower nonbankruptcy prediction accuracy can be seen even in MDA models. Given that these models do not exhibit as high non-bankruptcy prediction accuracy as the Ohlson model does, the differences between accuracies of bankruptcy and non-bankruptcy are not so notable.

Achieving greater predictive power for prediction of bankruptcy in a sufficient period before bankruptcy is important because the models are seen as early warning models. Identifying the risk of bankruptcy can ultimately prevent its occurrence, but recording the risk of bankruptcy in the period of more than 3 years ahead makes most of the models fail.

\subsection{Non-bankruptcy accuracy}

When evaluating the accuracy of non-bankruptcy prediction, we abstract from the results the Ohlson model achieves in response to the uncertainty in predicting bankruptcy, which can make the results skewed because most of the businesses are classified as prosperous.

When comparing MDA models while predicting non-bankruptcy one and two years ahead the best performance is achieved by index IN01, followed by Altman model. 
Index IN05 while predicting non-bankruptcy reaches the worst results, but in predicting bankruptcy had the highest accuracy. This phenomenon is due to the fact, that the index IN05 has a high error rate type II - many prosperous businesses were classified as bankrupt businesses, and therefore the bankruptcy of the company could not be correctly identified by the index. On the other hand, the greater number of bankruptcy predictions makes the probability of correct classification of the company as a bankrupted higher the index shows higher values of accuracy of bankruptcy prediction.

In the analysis of the accuracy of prediction of non-bankruptcy models in time we see an increase in the model accuracy in predicting two years ahead. Higher values in predicting bankruptcy are accompanied by a decrease in non-bankruptcy accuracy and vice versa. Therefore, while forming the model the dividing line should be appropriately determined, so it would achieve sufficient accuracy in predicting bankruptcy and non-bankruptcy.

\subsection{Summary}

Based on the above results of the validation of selected models the working hypothesis were assessed as follows:

Table 5. Summary of confirmation of working hypothesis

\begin{tabular}{lcc}
\hline \multicolumn{1}{c}{ Hypothesis } & $\begin{array}{c}\text { Total prediction } \\
\text { accuracy }\end{array}$ & $\begin{array}{c}\text { Bankruptcy } \\
\text { prediction accuracy }\end{array}$ \\
\hline $\begin{array}{l}\text { Working Hypothesis 1: Index IN 05 achieves higher } \\
\text { prediction accuracy than index IN 01 }\end{array}$ & rejected & confirmed \\
\hline $\begin{array}{l}\text { Working Hypothesis 2: Indices IN 01 and IN 05 achieve } \\
\text { higher prediction accuracy than Altman model }\end{array}$ & rejected & confirmed \\
\hline $\begin{array}{l}\text { Working Hypothesis 3: Ohlson model achieves higher } \\
\text { prediction accuracy than the MDA models }\end{array}$ & confirmed & rejected \\
\hline
\end{tabular}

From Table 5 it is obvious, that the rejection or the non-rejection of the hypothesis largely depends on what type of accuracy is being judged. As far as it is the assessment of the overall accuracy of the models, we have shown that the highest overall accuracy is reached by Ohlson model and thanks to a very high accuracy of non-bankruptcy that leads to a very low bankruptcy prediction accuracy we have rejected our working hypothesis No. 3, as Ohlson model was not able to predict bankruptcy in more than $35 \%$. While comparing the overall accuracy of IN indices and the Altman model we can see that none of the hypotheses could be confirmed because the index IN01 reaches a higher accuracy compared to the index IN05, while Altman model outperforms the index IN05. On the other hand, when evaluating the accuracy of prediction of bankruptcy, we received completely opposite results. The Ohlson model appeared to be the worst one and the best results in predicting ability were achieved by using the index IN05. These contrasting results are, as already mentioned, due to the fact, that the higher the accuracy of bankruptcy prediction - the lower the accuracy of the non-bankruptcy prediction. On these results we have shown that the different levels of accuracy bring different results. 
When making decision on what model is the most appropriate we have to look on the costs of wrong prediction. As the error of Type I (prediction of bankrupt company as a non- bankrupt) is higher than the error of Type II (prediction of non- bankrupt company as a bankrupt one) we should put emphasize on bankruptcy prediction accuracy (Bellovary et al. 2007; Kuo 2013; Gepp, Kumar 2008; etc.). In spite of this, many authors evaluate models only on the level of total accuracy. However, from what we showed in the analysis, if we take into account only total accuracy, the results depend only on the sample, resp. on the ratio of bankrupted and non-bankrupted companies, which determines the overall success of models. Hence, based on the results we can claim that the most appropriate model (from analysed models) is index IN05 as showed the highest predictive ability of bankruptcy and by this conclusion we have confirmed the result of Delina and Packová (2013) where authors showed the higher sensitivity of IN05 index on bankruptcy in comparison to Altman model.

\section{Discussion}

As mentioned above in the theoretical part of the paper, the development of models brings a wide range of constraints and opens discussion space over many application and dissemination lines as well. These restrictions should be reflected in each research study in order to create space for the creation of new models or the modifications of already developed ones. Long-term criticism of the Altman Z-score and the Ohlson $\mathrm{O}$-score was mainly related to the developing period (Altman's Z-score using data from 1946 to 1965, Ohlson's O-score from 1970-1976). Many authors have long questioned whether it is appropriate to apply these models in a period other than that in which they were created. They also call for the need analysis of the model stability at time of significant inflationary changes, interest rates movements, credit availability, changes in legislative conditions, and various political barriers and restrictions. The application of the Altman model is also questionable when using it in a different size of sample or other industry than used in the original model. This fact encouraged the creation of multiple variations of the conventional Z-score which reached increase in predictive capabilities even under the new changed conditions (Ko et al. 2017). Grice (Grice, Ingram 2001) reflected in his study on model criticism and proposed to use the re-estimation of the Altman's model coefficients using a proportionally divided sample. The same method in the form of re-estimating variables can be found also in study by Bod'a and Úradníček (2016). In order to increase the predictive ability of models, Almamy et al. (2016) conducted further analyses on the sample of UK companies consisted of data from time period 2000-2013. As the results, they proposed the extension of the Altman Z-score to a new variable, which was selected on the basis of discriminatory analysis and (performance ratios) statistically significant prediction of financial health of British companies. The prediction accuracy of their model was $82.9 \%$. Kral et al. (2016) compared original Altman's Z-score with the prediction models based on the other classification methods such as logistic regression, decision trees and random forests. The results pointed to the fact that the new models are better than the original Altman model in overall accuracy and specificity, but much worse results were demonstrated in the sensitivity even in the sensitivity-optimized models. They recommend to expand 
studies to other methods such as conditional tress, KNN (k-nearest neighbours), SVM (support vector machines), as well as to improve the prediction accuracy mainly by using balanced sampling of training sets and Cut-point selection. Interesting results from recent studies can be found by researchers Kumar and Rao (2015) who developed a "new multivariate nonlinear model for computing the Z-score" as well as "a new credit risk index by fitting a Pearson type 3 distribution to the transformed financial ratios". By their application they showed that the new Z-score predicts bankruptcy with an accuracy of $98.6 \%$, whereby original $\mathrm{Z}$ score reached $93.5 \%$. As in the case of the Altman model, even in the case of Ohlson there is a strong criticism of its applicability in relation to the period in which it was created and to the determinants that decisively influence the development of the economy and the processes associated with it. A critique of the Ohlson model can be found in the study of Robertson and Mills (1991), in which authors emphasize a significant constraint of the model when comparing the businesses from various industries. To eliminate the model limitation, many authors use the modified Ohlson model. For example, authors Ho et al. (2013) use the binary logit model based on the re-estimation of original Ohlson. The newly estimated Ohlson model correctly predicted $93 \%$ of bankruptcies. Lin (2009) tested modified models of original Altman and Ohlson models using Multiple Discrimination Analysis (MDA), logit, probit, and artificial neural networks (ANNs) on a sample of Taiwanese state-owned industries in 1998-2005. The results of his study proved that all new models used to show a higher predictive accuracy than the original models of Altman and Ohlson. Hwang, Cheng and Lee (2009) propose to use the logit model to re-estimate the Ohlson model and proved that the predictive ability of modified model is higher. Besides that, they propose to use not only accounting financial variables but even the market-driven ones. The same conclusion was made also by Das, Hanouna and Sarin (2009).

This cross-section of studies focused on the criticism of bankruptcy models is far from being exhausted; our ambition in this discussion was to emphasize the efforts of researchers to increase the predictability of models with minimal constraints through model modifications and the application of various support analyses, methods and tools. We can assume that, in the current after crisis period, increasing globalization, stronger competitive pressures, demands for availability and usability of high-quality prediction models will be higher and higher. On the other hand, even new models are created on the certain sample, thus are supposed to reach better results on the samples reflecting the similar conditions when comparing to the other conditions. The solution would be the realization of multidimensional analyses reflecting the dynamics of the development of the external environment of companies in the countries, which would quantify complex determinants influencing the changes in individual economic cycles in different sectors.

\section{Conclusions}

While validating the selected models: Altman model, indexes IN01 and IN05 and Ohlson model, we concluded that the Ohlson model is inappropriate in predicting the financial situation of enterprises in the Slovak Republic despite the fact, that its overall predictive ability is high. Its uselessness results from the insufficient level of bankruptcy 
prediction accuracy, resulting in the formation of errors type I with high costs (Bellovary et al. 2007; Kuo 2013; Gepp, Kumar 2008; etc.). This conclusion is supported also by findings of research conducted by Robertson and Mills (1991), Morris (1997), Giacosa et al. (2016), etc.

Within the MDA models, IN indices and Altman model reached comparable results. Selection of the appropriate MDA model in predicting the financial situation of enterprises largely depends on whether the user is willing to accept a higher level of errors of the first or second type. Generally speaking, the first type of error is more expensive - in this regard IN05 seems to be the most appropriate model which reaches the highest bankruptcy prediction accuracy. This conclusion is supported also by Delina and Packová (2013), Lesáková and Gundová (2015), Mihalovič (2015), etc.

It is also clear, that while creating models it is important to find balance between bankruptcy and non-bankruptcy prediction, which is often a complicated aim, because increasing accuracy in predicting bankruptcy is accompanied by a reduction of accuracy in predicting non-bankruptcy and vice versa. Based on our achieved results from the validation of the models, we can conclude that the overall accuracy of the models does not reach a sufficiently high value, as they do not exceed $75 \%$. This was mainly due to the following restrictions of models:

- Diversity of the sample consisting of Slovak enterprises compared to the sample, which the validated models were created on. Altman and Ohlson models were formed on a sample of US companies, while IN indices on a sample of Czech companies, as a result, these models reflect the financial health of companies specific to these conditions.

- The shift in the time period, in which the models were created and validated. IN index does not have any significant shift, but if we speak about Altman and Ohlson models, which were created in the 90 s of the 20th century, there was a significant shift in the structure of industries and businesses.

What needs to be pointed out is that, many authors evaluate models only on the level of total accuracy. However, from what we showed in the analysis, if we take into account only total accuracy, the results depend only on the sample, resp. on the ratio of bankrupted and non-bankrupted companies, which determines the overall success of models. Hence, our study brought deeper insight into the issue of validation and based on that we were able to find model that is the most appropriate for Slovak business environment - index IN05.

Our research is limited due to a number of factors related to the both, the nature of the analyzed data and the usefulness of the research results. The first problem that we encounter in research is the explanatory ability of financial statements of analyzed companies. Critics argue, that the approach of using the financial statements in both, the creation and validation of models ignores the possibility of errors, distortions or misstatements of financial variables, especially in companies with a deteriorating financial situation. Especially, the large companies are able to hide or distort data that are hard to be detected by auditors. One reason of the data distorting is also the effort 
of companies to pay as low tax as possible, thereby they try to reduce their accounting profit by changing the financial statement data. Data misstatements may also be due to the management attempt to delay the disclosure of information about the bankruptcy of the firm. As a result, predictive bankruptcy models based on such data can have lower explanation ability. The second limitation is the size of the sample. Based on the availability of the financial statements, most of the sample consists of data of bankrupted companies (only 20\%). Thus, a smaller number of bankruptcy businesses may result in a reduced ability of the model to classify a bankrupt of the enterprise correctly. Other research constraints mainly concern the use of the research results. Given that the analyzed sample consists only of Slovak companies, the results can be applicable only for states with similar conditions. By other words, when applying the same models on the other data, the results may vary, more or less, depending on the difference between the Slovak business environment and the other environment.

\section{Funding}

This work was supported by the Slovak Research and Development Agency under Grant number APVV-14-0841: Comprehensive Prediction Model of the Financial Health of Slovak Companies.

\section{Contribution}

Beata Gavurova initiated the research and the manuscript. Beata Gavurova and Miroslava Packova proposed the study design, performed data collection, the literature research and the interpretation of the data. Maria Misankova and Lubos Smrcka participated in the design of the structure of the article, the interpretation of the data and literary research and the preparation of the manuscript. All the authors contributed to the article and approved the final form of the manuscript.

\section{Disclosure statement}

Authors declare that they do not have any competing financial, professional, or personal interests from other parties.

\section{References}

Almamy, J.; Aston, J.; Ngwa, L. N. 2016. An evaluation of Altman's Z-score using cash flow ratio to predict corporate failure amid the recent financial crisis: evidence from the UK, Journal of Corporate Finance 36: 278-285. https://doi.org/10.1016/j.jcorpfin.2015.12.009

Altman, E. 1968. Financial ratios, discriminant analysis and the prediction of corporate bankruptcy, The Journal of Finance 23(4): 598-608. https://doi.org/10.1111/j.1540-6261.1968.tb00843.x

Altman, E. I. 1982. Accounting implications of failure prediction models, Journal of Accounting, Auditing, and Finance, fall, 4-19.

Altman, E. I. 1984. The success of business failure prediction models, Journal of Banking and Finance 8: 171-98. https://doi.org/10.1016/0378-4266(84)90003-7 
Anoop, J.; Banerjee, P.; Francis, V. 2007. Modeling and empirical validation of revised Altman's credit risk model for Indian banks [online], [cited 12 April 2017]. Available from Internet: http:// ssrn.com/abstract $=960213$

Araghi, M. K.; Makvandi, S. 2013. Evaluating the technique of data envelopment analysis in predicting bankruptcy, Journal of Basic Applied Science Research 3: 519-527.

Beaver, W. H. 1966. Financial ratios as predictors of failure, Journal of Accounting Research 4: 71-111. https://doi.org/10.2307/2490171

Bellovary, J. L.; Don Giacomino, E.; Akers, M. D. 2007. A review of bankruptcy prediction studies: 1930 to present, Journal of Financial Education 33: 1-42.

Bieliková, T.; Bányiová, T.; Piterková, A. 2014. Prediction techniques of agriculture enterprises failure, Procedia Economics and Finance 12: 48-56.

https://doi.org/10.1016/S2212-5671(14)00319-0

Blach, J.; Wieczorek-Kosmala, M. 2012. The ration analysis of financial balance and bankruptcy risk of the Silesian companies in time of the global financial crisis, Equilibrium 7(3): 111-126. https://doi.org/10.12775/EQUIL.2012.022

Bod'a, M.; Úradníček, V. 2016. The portability of Altman's Z-score model to predicting corporate financial distress of Slovak companies, Technological and Economic Development of Economy 22(4): 532-553. https://doi.org/10.3846/20294913.2016.1197165

Boratynska, K. 2016. Corporate bankruptcy and survival on the market: lessons from evolutionary economics, Oeconomia Copernicana 7(1): 107-129. https://doi.org/10.12775/OeC.2016.008

Bukovinsky, D. 1993. Cash flow and cash position measures in the prediction of business failure: an empirical study: $\mathrm{PhD}$ dissertation. University of Kentucky.

Charitou, A.; Neophytou, E.; Charalambous, C. 2004. Predicting corporate failure: empirical evidence for the UK, European Accounting Review 13(3): 465-497.

https://doi.org/10.1080/0963818042000216811

Das, S. R.; Hanouna, P.; Sarin, A. 2009. Accounting-based versus market-based cross-sectional models of CDS spreads, Journal of Banking \& Finance 33(4): 719-730.

https://doi.org/10.1016/j.jbankfin.2008.11.003

Delina, R.; Packová, M. 2013. Validácia predikčných bankrotových modelov v podmienkach SR [Validation of bankruptcy prediction models in the Slovak environment], E+M Ekonomie a Management 16(3): 101-112.

Ékes, K. S.; Koloszár, L. 2014. The efficiency of bankruptcy forecast models in the Hungarian SME sector, Journal of Competitiveness 6(2): 56-73. https://doi.org/10.7441/joc.2014.02.05

Erdogan, B. I. 2008. Bankruptcy prediction of Turkish commercial banks using financial ratios, Applied Mathematical Sciences 2(60): 2973-2982.

Gepp, A.; Kumar, K. 2008. The role of survival analysis in business failure prediction, International Research Journal of Finance and Economics 16: 13-34.

Giacosa, E.; Halili, E.; Mazzoleni, A.; Teodori, C.; Veneziani, M. 2016. Re-estimation of company insolvency prediction models: survey on Italian manufacturing companies, Corporate Ownership and Control 14(1): 159-174. https://doi.org/10.22495/cocv14i1c1p1

Grice, J. S.; Ingram, R. W. 2001. Tests of the generalizability of Altman's bankruptcy prediction model, Journal of Business Research 54(1): 53-61.

https://doi.org/10.1016/S0148-2963(00)00126-0

Gulka, M. 2016. Model predikcie úpadku obchodných spoločností podnikajúcich v podmienkach SR [Prediction model of Slovak companies], Forum Statisticum Slovacum 12(1): 16-22. 
Gundová, P. 2014. Verification of the selected prediction methods in Slovak companies, Acta Academica Karviniensia 4: 26-38.

Ho, C. Y.; McCarthy, P.; Yang, Y.; Ye, X. 2013. Bankruptcy in the pulp and paper industry: market's reaction and prediction, Empirical Economics 45(3): 1205-1232.

https://doi.org/10.1007/s00181-012-0661-6

Hwang, R. C.; Cheng, K. F; Lee, C. F. 2009. On multiple-class prediction of issuer credit ratings, Applied Stochastic Models in Business and Industry 25(5): 535-550.

https://doi.org/10.1002/asmb.735

Ingram, F. J.; Frazier, E. L. 1982. Alternative multivariate tests in limited dependent variable models: an empirical assessment, Journal of Financial and Quantitative Analysis 17(2): 227-240. https://doi.org/10.2307/2330848

Karas, M.; Reznakova, M.; Bartos, V.; Zinecker, M. 2013. Possibilities for the application of the Altman model within the Czech Republic. Recent Researches in Law Science and Finances, 203-207 [online], [cited 16 April 2017]. Available from Internet: http://www.wseas.us/e-library/ conferences/2013/Chania/ICFA/ICFA-30.pdf

Ko, Y. C.; Fujita, H.; Li, T. 2017. An evidential analysis of Altman Z-score for financial predictions: case study on solar energy companies, Applied Soft Computing 52: 748-759.

https://doi.org/10.1016/j.asoc.2016.09.050

Kordlar, A. E.; Nikbakht, N. 2011. Comparing bankruptcy prediction models in Iran, Business Intelligence Journal 4(2): 341-348.

Kral, P.; Fleischer, M.; Stachova, M.; Nedelova, G.; Sobisek, L. 2016. Corporate financial distress prediction of Slovak companies: Z-score models vs. alternatives, in AMSE 2016-19 $9^{\text {th }} \mathrm{Ap}$ plications of Mathematics and Statistics in Economics Conference Proceedings, 31 August - 4 September 2016, Banská Štiavnica, Slovakia.

Kumar, M. N.; Rao, V. S. H. 2015. A new methodology for estimating internal credit risk and bankruptcy prediction under Basel II Regime, Computational Economics 46(1): 83-102.

https://doi.org/10.1007/s10614-014-9452-9

Kumar, R. G.; Kumar, K. 2012. A comparison of bankruptcy models, International Journal of Marketing, Financial Services \& Management Research 1(4): 55-67.

Kuo, Y. 2013. Consideration of uneven misclassification cost and group size for bankruptcy prediction, American Journal of Industrial and Business Management 3(8): 708-714.

https://doi.org/10.4236/ajibm.2013.38080

Lanine, G.; Vennet, R. V. 2005. Failure prediction in the Russian bank sector with logit and trait recognition models. Working paper. Ghent University, Belgium [online], [cited 15 December 2016]. Available from Internet: http://citeseerx.ist.psu.edu/viewdoc/download?doi=10.1.1.90.26 85\&rep=rep1\&type $=$ pdf

Lennox, C. 1999. Identifying failing companies: a revaluation of the logit, probit and da approaches, Journal of Economics and Business 51: 347-364.

https://doi.org/10.1016/S0148-6195(99)00009-0

Lesáková, L'; Gundová, P. 2015. Návrh modifikovanej podoby modelu predikovania finančnej situácie slovenských podnikov [Modification of financial health prediction model for Slovak companies], Ekonomika a spoločnos' 16(1): 14-24.

Lifschutz, S.; Jacobi, A. 2010. Predicting bankruptcy: evidence from Israel, International Journal of Business and Management 5(4): 133-141. https://doi.org/10.5539/ijbm.v5n4p133

Lin, T. H. 2009. A cross model study of corporate financial distress prediction in Taiwan: multiple discriminant analysis, logit, probit and neural networks models, Neurocomputing 72(16): 3507-3516. https://doi.org/10.1016/j.neucom.2009.02.018 
Meeampol, S.; Lerskullawat, P.; Wongsorntham, A.; Srinammuang, P.; Rodpetch, V.; Noonoi, R. 2014. Applying emerging market Z-score model to predict bankruptcy: a case study of listed companies in the Stock Exchange of Thailand (Set), in Management, Knowledge and Learning. Human Capital Without Borders: Knowledge and Learning for Quality of Life, 25-27 June 2014, Portorož, Slovenia.

Mihalovič, M. 2015. Are Altman Z-score and IN05 index able to predict financial difficulties of Slovak companies? European Union Knowledge Economy Review 3(1): 24-32.

Mihalovič, M. 2016. Performance comparison of multiple discriminant analysis and logit models in bankruptcy prediction, Economics and Sociology 9(4): 101-118.

Morris, R. 1997. Early warning indicators of corporate failure. Aldershot, England: Ashgate Publishing Ltd.

Neumaierová, I.; Neumaier, I. 2005. Index IN05, in Evropské Finanční Systémy: Sborník Př́spěvkú z Mezinárodni Vědecké Conference, Masarykova univerzita v Brne, Brno.

Ohlson, J. 1980. Financial ratios, and the probabilistic prediction of bankruptcy, Journal of Accounting Research 18(1): 109-131. https://doi.org/10.2307/2490395

Pam, W. B. 2013. Discriminant analysis and the prediction of corporate bankruptcy in the banking sector of Nigeria, International Journal of Finance and Accounting 2(6): 319-325.

Paseková, M.; Fišerová, Z.; Bařinová, D. 2016. Bankruptcy in Czech Republic - from the perspectives of debtors, creditors, and the judiciary, 2008-2013, Journal of International Studies 9(1): 180-191.

Rajin, D.; Milenkovic, D.; Radojevic, T. 2016. Bankruptcy prediction models in the Serbian agricultural sector, Economics of Agriculture 63(1): 89-105. https://doi.org/10.5937/ekoPolj1601089R

Robertson, J.; Mills, R. 1991. The uses and abuses of corporate prediction models, Management Accounting 69(9): 20-22.

Soon, N. K.; Mohammed, A. A. E.; Ahmad, A. R.; Tat, H. H. 2013. Applicability of Altman's revised model in predicting financial distress: a case of PN17 companies quoted in Malaysian stock exchange, in Entrepreneurship vision 2020: innovation, development sustainability, and economic growth [online], [cited 18 April 2017]. Available from Internet: http://eprints.uthm. edu.my/4119/1/paper_35.pdf

Sulub, S. A. 2014. Testing the predictive power of Altman's revised Z' model: the case of 10 multinational companies, Research Journal of Finance and Accounting 5(21): 174-184.

Taffler, R. J. 1984. Empirical models for the monitoring of U.K. corporations, Journal of Banking and Finance 8(2): 199-227. https://doi.org/10.1016/0378-4266(84)90004-9

Tam, K. 1991. Neural network models and the prediction of bank bankruptcy, Omega 19: 429445. https://doi.org/10.1016/0305-0483(91)90060-7

Váchal, J.; Vochozka, M. et al. 2013. Podnikové ř́zení [Business management]. Grada Publishing a.s. 988 p.

Vavřina, J.; Hampel, D.; Janová, J. 2013. New approaches for the financial distress classification in agribusiness, Acta Universitatis Agriculturae et Silviculturae 61(4): 1177-1182.

https://doi.org/10.11118/actaun201361041177 
Beata GAVUROVA. PhD, MBA is an expert in finance, financial analysis and financial risk management. She focuses in her research work on issues of measurement and performance management in various sectors, process management and process optimization, strategic and performance benchmarking. Her dominant research area is the development and testing in management and performance measurement, evaluation of methodologies and preparing of application platform for innovative management and performance measurement with the support of ICT.

Miroslava PACKOVA. PhD focuses in her research especially on bankruptcy prediction, financial health of companies, public procurement and assessment of efficiency. She participates in research European projects devoted to ICT implementation into processes such as procurement or measurement of efficiency.

Maria MISANKOVA. PhD works as a lecturer at the Department of Economics at the Faculty of Operation and Economics of Transport and Communications od the University of Zilina. She focuses in her research especially on bankruptcy prediction and financial health of companies, credit risk management, financial markets, financial and strategic management. She has participated in four research projects dedicated to the issues of her interest.

Lubos SMRCKA. CSc works as a Senior Lecturer in the Department of Business Economics at the Faculty of Business Administration of the University of Economics in Prague. He deals with a risk management, personal and family finances and insolvency. Gradually, he acquired several professional specializations: tax advisor, broker, forensic expert in economy, prices, and valuation specialized in the valuation of securities, RM-S and stock exchange and business valuation, and administrator in insolvency. 